\title{
Identifying mechanisms influencing the emergence and success of innovation within national economies: a realist approach
}

\begin{abstract}
This paper uses data from recent OECD (2013b) and Cornell University et al. (2014) national innovation reports to explain Australia's poor innovation performance. We adopt a realist approach and apply the technique of retroduction to identify potential causes. Whilst our account is only preliminary, we contend that this technique provides the resources to uncover plausible causes for further, more detailed, causal analysis. We conclude that the retroductive method is one that can be applied to aggregated statistics more generally and could be used by analysts and policy makers in any jurisdiction.
\end{abstract}

\section{To appear in Policy Sciences}

\section{Authors}

\author{
- Paul Jackson \\ Centre for Innovative Practice, School of Business, Edith Cowan University, Joondalup, \\ Australia. Tel +61 863042340 p.jackson@ecu.edu.au \\ - Jochen Runde \\ Cambridge Judge Business School, University of Cambridge, Cambridge, UK \\ j.runde@jbs.cam.ac.uk \\ - Philip Dobson \\ Centre for Innovative Practice, School of Business, Edith Cowan University, Joondalup, \\ Australia.p.dobson@ecu.edu.au \\ - Nancy Richter \\ Alexander von Humboldt-Institut für Internet und Gesellschaft, Berlin, Germany \\ nancy.richter@hiig.de
}

\section{Keywords}

critical realism; innovation efficiency; innovation policy; 


\section{Introduction}

There are several well-known international comparative measures of national innovation countries can use to benchmark their innovation activity, assess their relative performance, and initiate policy discussions or further qualitative research. In this paper, we look at the current innovation performance of Australia as revealed by the OECD (2013b) and Cornell University et al. (2014) innovation reports. We find that Australia's innovation efficiency, that is, its ability to translate innovation capabilities into innovation outputs, is surprisingly poor.

Our ultimate aim is to support the development of effective policy responses in the area of national innovation. To this end, the aim of the current paper is to show how aggregated statistical data from reports of the above kind can be used to identify and understand causal mechanisms underlying the emergence and success of innovative practices. In particular, we intend to show how the technique of retroduction can be used to elicit such mechanisms from such data, and thereby to go beyond mere correlation and towards achieving a coherent causal explanation of Australia's innovation performance. On this approach, broadly associated with critical realism (Bhaskar 1978; Collier 1994; Lawson 1997b), things like human practices, structural conditions and policy interventions, are seen as causal factors that combine to form real, often interacting, causal mechanisms (Maxwell 2004; Pawson and Tilley 1997; Runde 1998).

Our argument begins with a brief section on national innovation, after which we describe the philosophical underpinnings of our approach. We then apply this approach to data from the OECD and Cornell University et al. innovation reports. The empirical analysis proceeds in three stages. In the first, we use the data to confirm the existence of the problem. In the second, we analyse and aggregate the data, looking for indicators of its possible causes. Aggregated statistics of this sort are an invaluable resource when examining national issues, since data collection at a national level is expensive, difficult and beyond the capacity of most research projects. There is also an increasing body of Open Government Data (ODG) provided by groups such as the OECD, IMF, state and federal governments, and universities (Thorhildur et al. 2013), which, given an appropriate methodological approach, could similarly be put to effective use. Finally, in the third stage, we gather secondary data from other sources to support the argument for the causal mechanisms identified at the second stage.

Whilst we do not pretend to provide the final word on the subject, we do provide a methodology for generating provisional, albeit in our view compelling, explanations for Australia's poor innovation performance. As Osborne \& Brown (2011) argue, public policy has been slow to integrate insights from the innovation research base. Our hope is that our proposed methodology might contribute to achieving a level of "practical adequacy" for policy analysts and decision makers, who are invariably forced to make policy recommendations based upon partial information about what are invariably complex, dynamic social systems (Pielke 2004; Sayer 1992; Butler et al. 2010).

\section{Innovation}

Innovation is the creation of novelty: "the development and adoption of new and improved ways of addressing social and economic needs and wants" (Kuhlmann et al. 2010). Being innovative is increasingly regarded as essential to firm survival, at the same time as accelerating rates of innovation are becoming increasingly disruptive to established firms, especially in areas that involve the Internet (Song et al. 2008; Wirtz et al. 2010). Barriers to entry are falling in many industries, due 
to Internet cloud services, utility computing infrastructure and cheap e-commerce software, which allow firms to introduce new products, services and business models quickly, cheaply and with a wide reach. While incremental improvement and adaptation of products, services and work processes is important, radical or breakthrough innovation that moves these beyond existing models (Christensen and Overdorf 2000; Danneels 2004) is also needed to compete in markets that may be highly disrupted by the Internet, mobile computing, social media and other new technology platforms (Barczak et al. 2009; Markham 2013). For a country like Australia, with a well-educated, tech-savvy population, innovation is an opportunity but also a threat due to the ease of entry for other nations.

All participants in national economies-whether they be small or large business, or government agencies and NGOs-are potential creators of innovation. And since innovation is increasingly seen as critical to national competitiveness and prosperity, it is no surprise that national policy makers should look to craft enabling conditions in which innovation flourishes. Policy formation of this kind is often based upon a view that a country embodies a "national system of innovation", consisting of elements such as R\&D outputs, business and public research organisations, funding and taxation arrangements, and support systems (Freeman 1995; Lundvall 2007; Edquist and Chaminade 2006). Implicit within this systems of innovation view is the assumption that the components of the system are causally related, and that interventions must be considered in terms of their overall effect within the operations of that system. In our view, empirical measures of the system and the correlations between them only form the starting point, albeit an important one, for the identification and analysis of such causes and effects.

National innovation systems process modelling has encouraged the development of various innovation efficiency measures that are used to measure how well national capacities are converted into innovation outputs. The usual approach is to assess the performance of national innovation systems through a simple linear, process-oriented analysis, where output factors such as patents and academic articles, are represented as flowing directly from a set of resources and capabilities such as $R \& D$, educated workers, institutions and funding. The efficiency of the overall process is then assessed in rather mechanical terms as the relationship between input and output factors. It is true that more nuanced versions of this approach are emerging. Thus Mahroum and Al-Saleh (2013) create an "Innovation Efficacy Index" which embodies a pre-defined model of learning and adoption at the national level to explain why some countries might be more efficient than others. And Liu et al. (2015) use network-based ranking to explore national characteristics as possible causes of innovation efficiency. However, even in studies of this sort, the focus tends to remain on relations between observables with little discussion of causal relations or the possible effects of what is not measured.

National policy development generally begins with a high-level and holistic view of a nation's innovation performance. Policy makers must use the data-and generally available aggregated information figures heavily here-to help establish the causal mechanisms affecting innovation performance. What is needed is a means of inquiry that facilitates moving from observed effects to non-observed and perhaps non-observable causes. This is crucial to the development of innovation policy. Only after causal mechanisms have been identified and understood is it possible to move on to the question of how their possible positive effects may be amplified or negative effects reduced. As Sharaput (2012) puts it with reference to innovation policy: "If government is to re-assert a role 
as a strategic player in the operation of the economy, then it becomes necessary to move beyond politically expedient benchmarks toward a deeper understanding of the effects of government policy on the behaviour of market actors." (p. 264).

\section{Critical realism}

Critical realism provides a relatively well-known philosophical foundation for causal explanations of social phenomena (Bhaskar 2010; Collier 1994; Lawson 1997b) and has been used to guide applied work in different areas of social research including management (Ackroyd and Fleetwood 2000; Clark et al. 2007; Connelly 2000; Kontos and Poland 2009), information systems (de Vaujany 2008; Horrocks 2009; Mingers et al. 2013; Dobson et al. 2013) and economics (Koutsouris 2012; Lawson 2006). In this paper we put it to work in the area of innovation policy, focusing specifically on the case of Australia. Our interest is in uncovering the causes of observed outcomes, the first step towards identifying factors that might be influenced to achieve policy targets.

Critical realism is a form of scientific realism in holding that the objects of scientific inquiry exist independently of that inquiry, that is, form part of a relatively stable and researcher-independent "intransitive" domain. This firm ontological stance runs in tandem with a modest epistemological position to the effect that scientific theories and explanations are always from a point of view, partial and revisable, and accordingly part of a contingent "transitive" domain. Advocates of critical realism warn against the "epistemic fallacy" of transposing the intransitive (ontic) into the transitive (epistemological) domain (Collier 1994), that many things in the world are not accessible to experience and that, even where they are, they are never experienced in a direct, unmediated way. An important advantage of critical realism over competing empiricist and interpretivist approaches is that it provides a systematic way of expressing and thinking about aspects of the world that are not directly observable.

At a very abstract level, critical realism advances a view of reality as "layered" in the sense in which what is given in experience (the "empirical") is ontologically distinct from, and often "out of phase with", what happens or is actualised (the "actual"). The actual is in turn ontologically distinct from an underlying and often unobservable reality of things, powers, mechanisms and so on that give rise to the actual (this is sometimes called the "deep" or, but misleadingly since the empirical and the actual are no less so, the "real"). While the terms may sound exotic, the underlying ideas are in fact straightforward and commonsensical. Thus someone reading a magnetic compass might experience a needle rotating around the dial as she turns around to orient herself (the empirical), where the direction of the needle at any moment (the actual) is the product of how the magnet interacts with the underlying and unobservable magnetic field of the earth and aligns itself to point to the magnetic poles (the deep).

We said we are interested in uncovering the causes that lie behind observed outcomes. Let us define a cause of any event or state of affairs $X$ as anything that contributes to $X$ coming about. We can then distinguish between causal factors, their capacities, and causal mechanisms. Causal factors are things in the world-objects, structural conditions and so on-residing in the causal history of whatever is to be explained. Capacities are powers those things have, but which may sometimes remain unexercised (thus a compass' power to orient its user may never be realised if, say, the compass has been mislaid or its owner doesn't know how to use it). Causal mechanisms, in turn, are the ways of operating (of ensembles of) causal factors once their capacities are being exercised. 
Causal mechanisms are important in policy making since they can be used to explain, "... how and why programs work (or fail to work) in different contexts and for different program stakeholders. This is where the explicit use of mechanisms can play an important role in assisting theory-oriented evaluators to articulate more precisely the causal linkages between programs and their desired effects" (Astbury and Leeuw 2010).

While causal factors are sometimes observable, their capacities and associated causal mechanisms are generally not. Proponents of critical realism are accordingly cut off from appealing to the usual observability criterion for the existence of a cause. What is proposed instead is a causal criterion, namely that a plausible case can be made for the existence of an unobservable cause if its observable effects can be explained as the (part-) product of its operation.

A key element of the ontology of critical realism is the view that the much of the world is "open", at least outside of situations of experimental control. The notion of an "open" system is most easily understood by contrasting it with one that is "closed". A closed system is one in which deterministic or stochastic regularities connecting actualities such as events or states of affairs occur (Lawson 2003). An open system is then one in which such regularities do not occur. Typically, and leaving aside exceptions of spontaneous closures such as the regular movement of celestial bodies, closed systems are the product of human intervention aimed at isolating an intrinsically stable causal mechanism from anything that might interfere with its operation (Lawson 2003, pp. 224). That is to say, the requisite separability and intrinsic stability are rarely found in nature and then especially so in the social domain. If this view is correct, then there are limits to the extent to which policy makers can exploit stable correlations between manipulable "policy levers" and desired policy outcomes.

\section{Social ontology}

Thus far we have described critical realism at an abstract level without distinguishing between the social and the natural realms. With respect to the former, critical realism offers a distinctive image of social reality as something that exists in its constant reproduction. This image is best captured by the "transformational model of social activity" associated with Bhaskar (1978) and Lawson (1995, 2003) and the "morphogenetic model" associated with Archer (1995). While they differ in their details, both models distinguish between human practices (agency) on the one hand and the domain of social rules, relations and positions (social structure) on the other, and both make the distinctive claim that human activities at all times presuppose and draw on pre-existing social structure and, in the process, unintentionally reproduce, and sometimes transform, that same structure. Social structure is a (structural) precondition for action, on this view, and therefore a cause of action. One of the most ubiquitous forms of social structure is the various social positions occupied by human actors (and indeed technological objects (Philip Faulkner and Runde 2009; P. Faulkner and Runde 2013; Lawson 2012)). As the locus of all kinds of rights and responsibilities that guide so much of what people do, these roles are an important source of the routinised aspect of much of social life.

This strong emphasis on social structure should however not be taken to imply that human activities are completely determined by structural conditions. Human actors are regarded as reflexive social agents, where reflexivity is "the regular exercise of the mental ability, shared by all normal people, to consider themselves in relation to their (social) contexts", and where the associated deliberations "form the basis upon which people determine their future courses of action - always fallibly and always under their own descriptions" (Archer, 2007, p. 4). Thus business managers, for example, are 
seen as having have the capacity to choose whether or not to enact or otherwise influence innovation activities. They are thus seen as potential prime movers in the sense that their decisions and the activities that flow from them can themselves be causal, leading to social change. Indeed, they may even have the capacity to "... contribute to the transformation of national innovation systems at large" (Hung and Whittington 2011).

\section{Descriptive statistics, event regularities and retroduction}

The purpose of applied critical realist analysis is to surface the underlying causes of whatever is under investigation. However, its commitment to much of the world being open and with interacting and often unobservable causes cuts it off from modes of analysis that privilege the discovery of sharp event regularities (e.g. standard correlation analysis such as in Walker (2006)). Yet a belief in open systems does not imply a denial of the existence of more or less rough patterns of events or what Lawson (1997a) calls "demi-regularities". Patterns in statistical indicators, such as the OECD scoreboard we go on to draw on below, are a form demi-regularity and draw our attention to the underlying processes that produce them (Zachariadis et al. 2013). However, rather than the discovery of such patterns being regarded as the goal of scientific research, as the standard view would have it, they are regarded as marking the point of entry for research as traces of underlying causes.

The recommended mode of inference for uncovering causes is retroduction, "the moment, on the basis of analogy and metaphor amongst other things, from a conception of some phenomenon of interest to a conception of some totally different kind of thing, mechanism, structure or condition that is responsible for the given phenomenon ... It is a movement, paradigmatically, from a 'surface phenomenon' to some 'deeper' causal thing" (Lawson 2003, p. 145). The movement is creative, a "conjecture of the mind" (Peirce 1911), and one in which counterfactual reasoning and contrast explanation often play a role. Counterfactual reasoning involves questions of the form "would $X$ have occurred in the absence of $Y$ ?", and where a negative answer points to $Y$ being a cause of $X$. Contrastive explanations are ones in which the aim is not to explain $X$, but to explain why $X$ rather than $Y$, where $X$ is something surprising and $Y$ is what we would ordinarily expect. The aim is then to attempt to uncover what might have caused the surprise. In the present case the surprise we seek to explain is why the innovation performance of Australia is poor by comparison with its peers, when it is so rich in innovation potential.

A good-but necessarily always provisional-causal explanation is one in respect of which the evidence is consistent with the causal factors cited having been present in the runup to the explanandum phenomenon, and where (1) their capacities were activated, (2) were not anticipated by alternative causes, and (3) not neutralised or offset by countervailing causes (Runde, 1998).

\section{Methodology}

Our purpose is to investigate the causal mechanisms that influence innovation in national economies from a critical realist perspective. It is generally accepted that realist analyses generally require the collection of rich, primary data (Maxwell 1992) to provide contextual information about the existence and activation of causal mechanisms in the situations under investigation. Such data may also direct the researcher towards other theories that reframe the issue and provide alternative explanations. However, we believe that a great deal can already be achieved by applying the technique of retroduction to secondary data that has been collated and summarised. That is to say, 
we believe that it is possible to use such secondary data to achieve satisfying, albeit provisional, causal explanations of innovative practice.

Our starting point is the innovation reports provided by Cornell University et al. and the OECD, probably the two most current and extensive international databases there are. Since the data provided in these reports are empirical statistical indicators, they are merely “... pointers ... [and] ... do not address causal relations" (OECD 2013b). The missing causal analysis is what we seek to provide below. Our investigation proceeds in three stages, following Wynn \& Williams (2012):

1. Empirical Corroboration: The first stage uses the Cornell University et al. and OECD data to support the surprising initial observation about Australia's poor performance in translating innovation inputs into outputs. The aim of the exercise here is to find whether the empirical data in these reports supports this observation and is confined to combining the observed data and examining relations between data points.

2. Retroduction: The second stage is to examine the data for clues about possible causes of the problem. We move recursively between the activities of retroduction, explicating the structure and context of innovation practice, and proposing explanations of the low levels of innovation. The Cornell University et al. survey contains 84 data points and the OECD survey 260. We examine each data point and extract data at the extremes and seek those that suggest structural conditions and mechanisms that may be an underlying drag on innovation. We consider how, within a national system of innovation, we can explain low innovation levels by invoking these conditions and mechanisms. The objective at all points is to identify causes that exist independently of their observation and have the power to influence outcomes.

3. Triangulation: The third stage is to strengthen and validate our account of the causes identified, which we do through using multiple sources of secondary data other than the OECD and Cornell University et al. reports. We need to confirm that the factors cited were indeed present, and their capacities activated and not anticipated or offset by other causes, to provide a "satisfactory" explanation of the situation concerned (Runde 1998). This is conducted from the desktop, and involves reviewing a wide range of reports and documentation from sources including the Australian Bureau of Statistics, Australian Department of Commerce and Industry reports, consulting reports and Australian Department of Innovation reports. The ancillary data analysed provides context and confirmation from different sources (such as education, demand-side marketplaces or government regulation).

We adopt the Context-Mechanism-Outcome (CMO) representation of Pawson \& Tilley (1997) to enable the capture and ordering of the data collected, and in Figure 1 we enhance this representation by distinguishing between the macro (national institutional and regulatory), meso (industrial and business) and micro (personal) strata to demonstrate the origin and effect of the mechanisms in play. Figure 2 provides a map of the causal factors and mechanisms identified, their interactions and co-dependencies (Maxwell 1992). Finally we subject the data to peer review by four researchers familiar with critical realism and its methods, innovation studies, economics and entrepreneurship. We make several changes to our causal model based upon these reviews. 


\section{Results}

\section{Stage 1 - Empirical Corroboration}

The Global Innovation Index 2014 is a survey by Cornell University, INSEAD and the World Intellectual Property Organisation (a UN organisation) of 143 countries' innovation performance. The overall innovation performance ranking of a country comprises two top-level sub-indices:

1. Innovation inputs are institutions, human capital and research, infrastructure, market sophistication and business sophistication.

2. Innovation outputs are knowledge and technology outputs and creative outputs.

A third top-level index is the innovation efficiency index, which is a simple ratio of outputs to inputs.

Each sub-area contains measures of innovation that, when combined, provide indirect indicators for that sub-area. For example, the rubric of "Institutions" consists of measures of the political, regulatory and business environment, each of which is then measured by proxy variables (e.g., the indicators for "political institutions" are stability, freedom of the press, and government effectiveness).

Australia is ranked 17th in the world in terms of overall innovation performance, which flows from it being ranked $10^{\text {th }}$ in innovation inputs and $22^{\text {nd }}$ in innovation outputs. However, its efficiency ratio is .70 , which leaves it $81^{\text {st }}$ in innovation efficiency out of the 143 nations measured. This is a surprisingly poor and concerning result. Were Australia to continue in this way, there would be a severe risk of future interventions to improve capabilities not gaining traction or doing so only at a higher than necessary cost (Guan and Chen 2012).

The Cornell University et al. survey measures innovation as knowledge and technology outputs using three sub-groups as proxy input variables:

- Knowledge creation-e.g. patents, publications, citations (Australia is ranked $26^{\text {th }}$ )

- Knowledge impact-e.g. GDP growth per person engaged, new business density, software spending, high-tech outputs (Australia is ranked $34^{\text {th }}$ )

- Knowledge diffusion-royalties, high-tech exports, FDI outflows (Australia is ranked $78^{\text {th }}$ )

The knowledge impact and knowledge diffusion indicators are particularly poor (see Table 1). Australia ranks well in scientific publications $\left(12^{\text {th }}\right)$ and citable documents $\left(10^{\text {th }}\right)$, which are largely products of public research institutions. But a low growth rate of GDP per person $\left(41^{\text {st }}\right)$, and poor use and creation of high tech outputs lead to low composite rankings. Whilst not an unproblematic gauge, the degree to which domain knowledge from diverse, non-ICT industries is embedded via ICT into products and services is generally suggestive of levels of innovation outputs (Godin 2004). These indicators point directly to low innovation performance in the business sector in Australia. As Rammer (2006) points out, "indicators on innovation in firms rather provide a crucial link between input and output indicators of technological performance and help to understand why performance in sciences, R\&D and patenting may differ from performance in productivity, structural change and exports in high-technology goods" (p. 108).

Table 1: Australia's Knowledge and Technology Outputs Rankings (Cornell University et al. 2014)

\begin{tabular}{|l|l|}
\hline Knowledge \& Technology Outputs & World Rank \\
\hline
\end{tabular}




\begin{tabular}{|l|c|}
\hline Knowledge creation & $\mathbf{2 6}$ \\
\hline National office resident patent applications & $\mathbf{4 0}$ \\
\hline Patent Cooperation Treaty resident applications & 26 \\
\hline National office resident utility model applications & 26 \\
\hline Scientific and technical publications & 12 \\
\hline Citable documents H index & 10 \\
\hline Knowledge Impact & 34 \\
\hline Growth Rate of GDP per person engaged & 41 \\
\hline New business density & 8 \\
\hline Total computer software spending & 31 \\
\hline ISO 9000 quality certificates & 49 \\
\hline High-tech and medium-high-tech output & 54 \\
\hline Knowledge diffusion & 78 \\
\hline Royalties and license fees receipts (\% service exports) & 32 \\
\hline High-tech exports & 56 \\
\hline Communications, computer and information services exports, \% & 87 \\
\hline Foreign direct investment net outflows & 49 \\
\hline
\end{tabular}

A similar picture emerges in the OECD (2013b) report. The OECD has been collecting data in its Science, Technology and Innovation Scorecard for a number of years. This scorecard confirms the indicators from the Cornell University et al. report on Australia's business innovation performance. The headlines are as follows:

- In the IP bundle (patents, trademarks and industrial designs, the three main legal devices used to protect innovations developed within firms), of the top 20 applicants from a country for protection, Australia is the lowest in the OECD (p. 186)

- In the creation of trademarks intended to protect knowledge based capital (KBC) generated in services and activities (rather than products for example), Australia is third lowest in the OECD (p. 190)

- In the creation of R\&D-related and ICT-related trademarks, measured by the number of applications from the top 20 applicants from a country, Australia is amongst the lowest in the OECD (p. 191)

- In product designs related to ICT and audio-visual innovation, measured by the number of applications from the top 20 applicants from a country, Australia is the lowest in the OECD (p. 193)

- In triadic patent families per head of population, Australia is $24^{\text {th }}$, at the bottom of the advanced economies (p. 57). Triadic patent families are patents applied for at the European Patent Office, the Japan Patent Office and the United States Patent and Trademark Office, to protect the same invention.

The poor performance of business in producing patents, trademarks and designs is consistent with the low research intensity reported in the Scorecard. With 2.47 researchers per 1000 population, Australia at $23^{\text {rd }}$ has one of the lowest number of researchers per capita in business (half the OECD average), and yet one of the highest at universities at 4.89 (OECD 2011, p. 74). So while Australian universities perform strongly in the production of research and graduates, this clearly does not translate into business innovation. 
The suggestive indicators in Table 2 are taken as empirical signs of underlying structures and their generally innovation-enhancing condition. We propose mechanisms through which these structures exert their powers. The indicators suggest supportive structural conditions that underscore how poorly the Australian business sector performs in translating Australia's relatively strong position with respect to innovation inputs, such as education, R\&D capacity, institutions and infrastructure, into innovation outputs. These inputs are typically regarded as key determinants of the effectiveness of a national innovation system (Kuhlmann et al. 2010) and yet, surprisingly, do not translate into high business innovation performance. 
Table 2: Key indicators, structural conditions and innovation-enhancing mechanisms

\begin{tabular}{|c|c|c|c|}
\hline $\begin{array}{l}\text { Suggestive indicators (Cornell University et } \\
\text { al. 2014, p145) }\end{array}$ & Suggestive indicators (OECD, 2013) & Structures: Structural conditions & Mechanisms \\
\hline $\begin{array}{l}\text { 2.3 Research and Development composite, } \\
8^{\text {th }} \\
\text { 2.3.2 Gross expenditure on R\&D, \%GDP, } 13^{\text {th }} \\
\text { 2.3.3 University ranking, top } 3,5^{\text {th }} \\
\text { 6.1.4 Scientific and technical articles, } 12^{\text {th }} \\
\text { 6.1.5 Citable documents } \mathrm{H} \text { index, } 10^{\text {th }} \\
\text { 2.2.1 Tertiary enrolments } \% \text { gross, } 7^{\text {th }}\end{array}$ & $\begin{array}{l}\text { p. } 94, \text { graduation rates at doctoral level, } \\
2000 \text { and } 2011,12^{\text {th }} \\
\text { p. } 103,59 \% \text { of basic research performed by } \\
\text { universities } \& \text { government, } 15^{\text {th }}\end{array}$ & $\begin{array}{l}\text { Universities: High performing universities in } \\
\text { producing } R \& D\end{array}$ & $\begin{array}{l}\text { Universities generate good-quality research } \\
\text { that is made publicly available. There is } \\
\text { significant opportunity for businesses to } \\
\text { pursue innovation activities by exploiting } \\
\text { this research and the expertise of university } \\
\text { researchers. }\end{array}$ \\
\hline $\begin{array}{l}\text { 2.1.3 School life expectancy } 1^{\text {st }} \\
\text { 2.1.4 Assessment in reading, writing, } \\
\text { mathematics, } 14^{\text {th }}\end{array}$ & $\begin{array}{l}\text { p. } 90 \text {, science reading and maths proficiency } \\
\text { at } 15,4 \text { th } \\
\text { P91, entry rate into tertiary education, } 2 \text { nd }\end{array}$ & Schools: High performance of school system & $\begin{array}{l}\text { An inclusive, meritocratic schooling system } \\
\text { produces students proficient in science and } \\
\text { mathematics who progress into the tertiary } \\
\text { system. They have the opportunity to } \\
\text { pursue courses of study that provide them } \\
\text { with the skills that, in the wider economy, } \\
\text { are the basis for innovative products and } \\
\text { services. }\end{array}$ \\
\hline $\begin{array}{l}\text { 1.1Political environment, stability, } \\
\text { government and press, } 14^{\text {th }} \\
\text { 1.2 Regulatory environment, } 12^{\text {th }} \\
\text { 1.2.1 Regulatory quality, } 7^{\text {th }} \\
\text { 1.2.2 Rule of law, } 12^{\text {th }}\end{array}$ & $\mathrm{N} / \mathrm{A}$ & $\begin{array}{l}\text { Legal and regulatory institutions: Stable and } \\
\text { effective regulatory system and institutions }\end{array}$ & $\begin{array}{l}\text { The stable legal, regulatory and political } \\
\text { system provides an ideal environment for } \\
\text { business managers to plan for innovation } \\
\text { and its anticipated payback. }\end{array}$ \\
\hline $\begin{array}{l}\text { 5.1.3 R\&D performed by business, \% GDP. } \\
16^{\text {th }} \\
4.3 .3 \text { Intensity of local competition, } 11^{\text {th }} \\
\text { 1.3.1 Ease of starting a business, } 9^{\text {th }} \\
\text { 1.3.2 Ease of resolving insolvency, } \\
17^{\text {th }}\end{array}$ & $\begin{array}{l}\text { p. } 226 \text {, enterprises selling online, } 1^{\text {st }} \\
\text { p. } 96 \text {, doctorate holders in the working age } \\
\text { population, } 12^{\text {th }}\end{array}$ & $\begin{array}{l}\text { Business people and commercial } \\
\text { institutions: High business sophistication } \\
\text { and levels of knowledge workers }\end{array}$ & $\begin{array}{l}\text { While competitive, the business } \\
\text { environment is straightforward to navigate. } \\
\text { Skilled and business-savvy workers have the } \\
\text { resources and capacity to recognise, reflect } \\
\text { upon and evaluate challenges in their } \\
\text { business domains, and develop innovative } \\
\text { solutions and responses to threats and } \\
\text { opportunities. }\end{array}$ \\
\hline
\end{tabular}


In knowledge creation, Australia performs well in publications $\left(12^{\text {th }}\right)$ and citable documents $\left(10^{\text {th }}\right)$, reflecting the relative success of universities. This is confirmed in the Research \& Development section of the report, where Australia ranks number 8 , and in particular in measures for:

- Gross expenditure on R\&D $\left(13^{\text {th }}\right)$

- QS university ranking average score of top 3 universities $\left(5^{\text {th }}\right)$

The numbers from the OECD Scorecard confirm Australia's poor innovation efficiency: low innovation output in spite of a relatively strong innovation capability. We now move on to the second stage of our analysis, where we review other indicators from the Cornell University et al. and OECD indices to identify mechanisms and contextual factors that might be inhibiting innovation translation.

\section{Stage 2 - Retroduction}

Both the Cornell University et al. and the OECD data were examined in detail to identify indicators that might signal mechanisms that may be acting as a drag on innovation in the business sector. We proceeded on the basis that a poor score, or an unexpectedly (anomalous) low score, might point to structures that play a part in inhibiting the translation of strong innovation inputs into innovative outputs. Reviewing all 344 data items, we came to a list of indicators that either surprised us or that pointed to potential causes of poor business innovation performance. We then sorted these into groups on the basis of which we could retroduce specific underlying structural conditions and possible causal mechanisms that might inhibit business managers' innovation efforts (Table 3 ). 


\begin{tabular}{|c|c|c|c|}
\hline $\begin{array}{l}\text { Suggestive indicators (Cornell } \\
\text { University et al. 2014, p145) }\end{array}$ & Suggestive indicators (OECD, 2013) & Structures: Structural conditions & Mechanisms \\
\hline $\begin{array}{l}\text { 4.2.1 Ease of protecting investors, } 55^{\text {th }} \\
\text { 5.2.3 R\&D financed by abroad, } 76^{\text {th }} \\
\text { 5.3.4 FDI net inflows, } \% \text { GDP, } 42^{\text {nd }}\end{array}$ & $\begin{array}{l}\text { p. 101, direct government funding of } \\
\text { business, Australia is about fourth lowest } \\
\text { p. } 108 \text {, business enterprise R\&D funded } \\
\text { from abroad, } 6^{\text {th }} \text { lowest } \\
\text { p. } 185 \text {, firms receiving government support } \\
\text { for innovation, lowest in OECD } \\
\text { p. } 185 \text {, firms receiving government support } \\
\text { for innovation, manufacturing \& services, } \\
2^{\text {nd }} \text { lowest }\end{array}$ & $\begin{array}{l}\text { Funding for business enterprise } \\
\text { innovation: Low budget allocations }\end{array}$ & $\begin{array}{l}\text { Low levels of direct funding for innovation } \\
\text { within the firm, parent firm, or from the state, } \\
\text { restrict the resources required for innovation in } \\
\text { new products and services. The indifference or } \\
\text { even resistance to innovation displayed by } \\
\text { organisational leaders discourages managers } \\
\text { and staff from taking risks with limited funding. }\end{array}$ \\
\hline $\begin{array}{l}\text { 2.2.2 Graduates in science \& engineering, } \\
65^{\text {th }} \\
\text { 3.3.1 GDP / unit of energy, } 66^{\text {th }} \\
\text { 5.3 Knowledge absorption composite, } 42^{\text {nd }} \\
\text { 5.3.3 Communications, computers and } \\
\text { services imports, } 86^{\text {th }}\end{array}$ & $\begin{array}{l}\text { p. } 162, \text { ICT expenditure as } \% \text { of GDP, } 5 \text { th } \\
\text { lowest } \\
\text { p. } 86, \text { spending on higher education, below } \\
\text { OECD average } \\
\text { p. } 92, \text { human resources in science \& } \\
\text { technology, below Euro average } \\
\text { p. } 95, \% \text { of doctor graduates in science and } \\
\text { engineering, } 22 \text { nd in OECD } \\
\text { p. } 99, \text { researchers in business, sector } 5 \text { th } \\
\text { lowest in OECD }\end{array}$ & $\begin{array}{l}\text { Workforce education and skills: Low } \\
\text { graduations in ICT / STEM (science, } \\
\text { technology, engineering, maths) subjects }\end{array}$ & $\begin{array}{l}\text { A paucity of graduates in technical disciplines } \\
\text { inhibits innovation that requires engineers and } \\
\text { ICT specialists. Since education in STEM subjects } \\
\text { raises understanding of what is possible as well } \\
\text { as the capability to execute, the low number of } \\
\text { STEM graduates inhibits the emergence of new } \\
\text { ideas, the initiation of new processes to exploit } \\
\text { these ideas, and that these ideas and processes } \\
\text { come to the attention of managers. }\end{array}$ \\
\hline $\begin{array}{l}\text { 2.2.4 Gross tertiary outbound enrolment, } \\
86^{\text {th }} \\
4.3 .1 \text { Applied tariff rate, weighted mean, } \\
45^{\text {th }} \\
4.3 .2 \text { Non-agricultural market access } \\
\text { weighted tariff } \%, 56^{\text {th }} \\
\text { 5.1.6 GMAT test takers / mn pop, } 33^{\text {rd }} \\
\text { 5.2 Innovation linkages, } 36^{\text {th }} \\
\text { 6.2.1 Growth rate of PPPS GDP/worker, } \% \text {, } \\
93^{\text {rd }}\end{array}$ & $\begin{array}{l}\text { p. } 203 \text {, barriers to entrepreneurship, } \\
\text { Australia is } 9^{\text {th }} \text { worst } \\
\text { p. } 36 \text {, Australia has around the } 4 \text { th lowest } \\
\text { labour productivity growth } 2001-2007\end{array}$ & $\begin{array}{l}\text { Managerial capability: Poor management } \\
\text { culture by international standards }\end{array}$ & $\begin{array}{l}\text { Where management capability is low, managers } \\
\text { often fail to create an environment in which } \\
\text { staff will risk their energy and ideas: managers } \\
\text { protected by tariffs and not pursuing higher } \\
\text { qualifications, tend to be isolated, do not look } \\
\text { over the horizon, are not aware of the speed of } \\
\text { the global market, do not sense or respond to } \\
\text { emerging threats. Such managers do not know, } \\
\text { understand, or care, how to sustainably } \\
\text { implement products or processes that are new, } \\
\text { original and risky. }\end{array}$ \\
\hline $\begin{array}{l}\text { 3.3 Ecological sustainability, } 37^{\text {th }} \\
\text { 3.3.1 GDP/unit of energy use, } 2000 \\
\text { PPP\$/kg oil eq, } 66^{\text {th }} \\
\text { 6.2.5 High- } \& \text { medium-high-tech } \\
\text { manufactures, } 54^{\text {th }} \\
\text { 6.3.2 High-tech exports less re-exports, }\end{array}$ & $\begin{array}{l}\text { p. } 38 \text {, investment in physical and } \\
\text { knowledge based assets: Very high in } \\
\text { physical assets, very low in software and } \\
\text { human capital } \\
\text { p. } 41 \text {, foreign value added content, very } \\
\text { low }\end{array}$ & $\begin{array}{l}\text { Industrial sectors: Dominance of low value } \\
\text { adding industry sectors }\end{array}$ & $\begin{array}{l}\text { The aggregate innovation performance of } \\
\text { economies dominated by low value adding } \\
\text { industries, tends to be negatively affected by } \\
\text { such industries investing relatively little in } \\
\text { technology and innovation. While managers in } \\
\text { these industries often seek to automate using }\end{array}$ \\
\hline
\end{tabular}




\begin{tabular}{|c|c|c|c|}
\hline $\begin{array}{l}\text { Suggestive indicators (Cornell } \\
\text { University et al. 2014, p145) }\end{array}$ & Suggestive indicators (OECD, 2013) & Structures: Structural conditions & Mechanisms \\
\hline $\begin{array}{l}56^{\text {th }} \\
\text { 6.3.3 Comm., computer \& info. services } \\
\text { exports, } 87^{\text {th }} \\
7.1 \text { Intangible assets (composite), } 45^{\text {th }} \\
7.2 .1 \text { Cultural \& creative services exports, } \\
\% \text { total trade, } 64^{\text {th }} \\
7.2 .2 \text { National feature film } / \mathrm{mn} \text {. Pop., } 49^{\text {th }} \\
7.2 .5 \text { Creative goods exports, } 52^{\text {nd }}\end{array}$ & $\begin{array}{l}\text { p. } 48,50 \% \text { of manufacturing exports are } \\
\text { high energy (metals, chemicals, coke) } \\
\text { p. } 46, \text { natural resource rents as a } \% \text { of GDP, } \\
\text { Australia is } 4^{\text {th }} \\
\text { R\&D funding specialisation as } \% \text { of R\&D } \\
\text { expenditure: } 30 \% \text { on mining (almost } \\
\text { unique) } \\
\text { p. } 219 \text {, top } 4 \text { exports: mining } 60 \% \text {, wood } \\
\text { and papers } 11 \% \text {. } \\
\text { p. } 243 \text {, services component of } \\
\text { manufactured exports is } 6^{\text {th }} \text { lowest } \\
\text { p. } 250 \text {, domestic value add in foreign final } \\
\text { demand, } 6^{\text {th }} \text { lowest } \\
\text { p. } 254 \text {, jobs in business sector sustained by } \\
\text { foreign demand } 15 \% \text {, third lowest. } \\
\text { p. } 255, \text { revealed comparative advantage in } \\
\text { exports of machinery and equipment, } 2^{\text {nd }} \\
\text { lowest }\end{array}$ & & $\begin{array}{l}\text { sophisticated equipment, in the Australian case } \\
\text { the technology is usually imported, making } \\
\text { them users, not producers, of innovation. While } \\
\text { There is sometimes scope for innovation if the } \\
\text { product can be enhanced by further processing, } \\
\text { making the process more complex, this is } \\
\text { something that requires funding and } \\
\text { progressive managerial skills that are generally } \\
\text { less available in simple industries. }\end{array}$ \\
\hline $\begin{array}{l}\text { 2.2.4 Gross tertiary outbound enrolment, } \\
86^{\text {th }} \\
5.2 \text { Innovation linkages, } 48^{\text {th }} \\
\text { 5.2.2 State of cluster development, } 34^{\text {th }} \\
\text { 5.2.3 R\&D financed by abroad, } 76^{\text {th }}\end{array}$ & $\begin{array}{l}\text { p. } 55 \text {, no ICT, biotech innovation hotspots } \\
\text { in Australia } \\
\text { p. } 126 \text {, firms collaborating on innovation } \\
\text { activities. } 32 \% \text { of large firms, } 4^{\text {th }} \text { lowest } \\
\text { p. } 127 \text {, firms doing R\&D and engaging in } \\
\text { collaboration, } 4^{\text {th }} \text { lowest } \\
\text { p. } 127 \text {, firms collaborating with higher } \\
\text { education or public agencies, } 3 \% \text {, lowest in } \\
\text { the OECD } \\
\text { p. } 127 \text {, large firms collaborating with } \\
\text { suppliers and clients, lowest in the OECD. } \\
\text { p. } 129 \text {, international collaboration by firms, } \\
15 \%, 3^{\text {rd }} \text { lowest }\end{array}$ & $\begin{array}{l}\text { Business collaborative networks: Low } \\
\text { levels of collaborating businesses }\end{array}$ & $\begin{array}{l}\text { Innovation is often fuelled by the exchange of } \\
\text { ideas in collaborative relationships, be this in } \\
\text { the form of generating new ideas and creative } \\
\text { synergies or simply boosting energy and } \\
\text { enthusiasm. The absences of such relationships, } \\
\text { be they between firms engaged in the same or } \\
\text { similar areas of activity, between firms and their } \\
\text { clients and suppliers, or between firms and } \\
\text { public bodies, is accordingly something that } \\
\text { inhibits innovation. }\end{array}$ \\
\hline
\end{tabular}


All of these mechanisms, directly or indirectly, represent a drag on innovation. However, it is not necessarily the case that they can effectively be tackled individually. For example, it is quite possible that policies aimed at counteracting one or other of these mechanisms may fail in the face of other countervailing mechanisms. For example, consider the question of whether the impact of low funding might be offset by direct grants to industry from Government to boost real innovation outputs. The answer might be no, if there is insufficient market demand in Australia for innovative products, or in the absence of the skills required to design and produce them. So we need to ask further questions of these mechanisms, to understand antecedent causes and factors that influence their activation and operation. In the next section we go beyond the Cornell University et al. and OECD statistics to examine reports and other research that may help confirm or invalidate these proposals.

\section{Stage 3 - Triangulation}

The final stage of our analysis involved providing an initial validation of the possible mechanisms we have identified. The primary resources we had to do so were other studies or data linking the mechanisms involved to innovation outcomes, or readily identifiable factors within the Australian context that might reasonably confirm the presence of the mechanisms and explain their likely inhibition of innovation activity in business enterprises.

Mechanism: Firms do not have the funding required to allocate resources to the development of new products and services or expand their markets. There are various factors that point to innovation being inhibited by low available funding. Direct funding by government of business enterprise innovation is the third lowest in the OECD (2013b), for example, and current government policy for innovation funding favours indirect tax relief over direct funding. Australia ranks $73^{\text {rd }}$ in the world in government procurement of advanced technology products (World Economic Forum 2014). In addition, the government is currently reducing its local level of manufacturing and high-tech procurement in defence spending (Nicholson 2014; Shepherd 2013), and this where Australia ranks $21^{\text {st }}$ in the OECD in venture capital investment as a percentage of GDP (OECD 2013a). Finally, while foreign ownership of Australian companies is high, the companies concerned invest very little in R\&D within Australia. It is not clear why this is the case, as foreign ownership can increase business R\&D spending (Bertrand 2009). This low level of investment may be related to the relative simplicity and low value-add of Australian manufacturing and industry, the high Australian cost base, or the absence of the required skills.

Mechanism: The low presence of ICT / STEM (science, technology, engineering and mathematics) skills restricts the ability of business to envision and implement innovation. Whereas Australia ranks $4^{\text {th }}$ in the OECD report (p. 90) for proficiency in science reading and mathematics proficiency at 15 years of age, only $16 \%$ of students study STEM subjects (as compared with $52 \%$ of tertiary students in Singapore (PriceWaterhouseCoopers 2014).

Australia has no national skills strategy in tertiary education, but rather a market-led policy in which "the study choices of students in Year 10 can influence the skills available to our workforce four to six years later ..." (Trounson 2014). At issue here is the composition of the demand for skills. In some cases, innovation intensive industries may actually be shrinking, such as in the case of the 
clean energy sector being frozen due to the uncertainty created by the policies of the incumbent conservative party. More important, however, is the preponderance of sectors in the Australian economy in which technology does not play an important role. The principal case in point here is mining, a sector that has experienced a significant boom in the wake of Chinese demand for minerals and energy, but which reflects a low volume and penetration of ICT as compared with manufacturing or finance (Potter et al. 2013). While the mining boom during the construction phase demanded skills in construction, generally trades and labour, and engineering and ICT, and while Australia is an important producer of mining technology, representing $4.6 \%$ of goods and services exports (ABS, 2009 in (Warren 2012)), mining is the industrial sector with the lowest expenditure on ICT as a percentage of revenue.

Mechanism: The low capability of managers to employ soft skills and creative techniques inhibits innovation and the creation of environments in which innovation prospers. Management capability, a key factor in initiating and sustaining innovation activity, is lacking in Australia. Due largely to China's demand for its natural resources, Australia has been highly successful economically, in spite of the global financial crisis of 2008. Employment has been high and general economic performance amongst the best in the OECD. One of the consequences of this success is an under-appreciation of the need to innovate in order to flourish, or even a perception in business that management skills might need improvement. Australian business culture has accordingly been described as one with significant gaps "in the areas of entrepreneurship, global orientation, soft skills, strategic skills and management development" (Karpin 1995), a view confirmed in a subsequent innovation report by Cutler (2008), who found consistent evidence of a lack of managerial capabilities (p. 56). As Dodgson and Innes (2006) put it in their international comparative survey:

Unlike their European counterparts, there is little evidence that Australian manufacturers see innovation as a tool to transform the way they do business or to respond proactively to the problems and/or opportunities presented by an increasingly globalised, knowledge-intensive marketplace. European firms were two-and-a-half times more likely to consider innovation/technology as an important factor for their competitiveness...The Australian firms in the sample have short-term planning horizons and are not adopting the formal continuous improvement processes that drive sustained step-change improvements as a coherent innovation strategy for long term competitive advantage. (p. 4)

In short, Australian management capability and innovation culture is poor by international standards (Australian Government Department of Industry 2012). When benchmarked against other countries, Australian managers "were found to be lagging world best practice in all 18 dimensions analysed, especially people management and 'instilling a talent mindset', which might be seen as a proxy for innovation capability" (Green and Logue 2009). Whilst education is critical, the low managerial drive to innovate is most likely to be a result of a low business mandate for innovative products and services from senior decision makers and perhaps customers, as well as a low personal perception of the need for innovation. This is most trenchantly reflected in market sector productivity, where " 8 of the 12 industries recorded negative MFP growth in 2012-13" (Productivity Commission 2014).

Mechanism: the dominance of simple low value-adding industry types leads to a low demand for innovation activities. The restricted opportunity for innovation in industry sectors in which 
technology does not play a dominant role affects innovation in direct and indirect ways. In particular, low value-adding industries display a low need to collaborate, and a low presence of ICT and STEM skills.

Australia's reliance on mining to generate exports is fundamental here. Fifty three per cent of Australia's total export revenue is derived from mining (Australian Bureau of Statistics 2013b), but which accounts for only 2.3\% of employed persons (Australian Bureau of Statistics 2013a). Sophisticated, but generally imported, capital equipment is used (Reserve Bank of Australia 2011). In the manufacturing sector, which accounts for $8.4 \%$ of employed persons, half of export revenue is generated by low value-adding, high-energy products such as chemicals, coke and paper (OECD, 2013, p. 48). Tellingly, Australia's top three exporting industries by percentage of total primary and manufactured goods-mining, chemicals and energy-are the bottom three for relative expenditure on ICT, a key measure of innovation (Potter et al. 2013). The value chains in these industries are comparatively simple, with a low level of ICT sophistication relative to other sectors, and therefore offer fewer opportunities to innovate. They also differ in their propensity to encourage research and collaboration, with chemicals for example demonstrating low research intensity and low collaboration (Hagedoorn 1993). We believe that the preponderance of unsophisticated production in Australia contributes significantly to low innovation levels: if an industry is simple, with low levels of embedded technology, and few value-add steps, the opportunities and need for collaboration and innovation are limited compared to industries such as complex manufacturing and high technology. Simpler production modes will in most cases involve simpler interactions that require less in the way of sophisticated ICT than do more complex modes.

Mechanism: Low levels of firm-firm and firm-institution collaboration inhibit the creation of synergistic relationships and opportunities for innovation. It is often observed that "[f]irms do not normally innovate in isolation but in continuous interaction with their environment, including the users of their products and other actors such as universities, suppliers, or other firms" (Edquist and Chaminade 2006). The absence of such collaboration leads to the loss of creative synergies that lead to innovation. It is therefore of some concern that levels of collaboration between Australian businesses and other institutions, be these universities, partners, customers or suppliers, are amongst the worst in the OECD.

The period between 2001 and 2011 saw a decline from 7.6 to 3.1 in the percentage of ideas for innovation sourced by businesses from universities (Australian Bureau of Statistics 2012, 2003). Given that the universities performed relatively well in producing new ideas over the period, this statistic suggests mechanisms predisposing Australian business against collaboration. As mentioned in the previous section, the drive to develop collaboration and innovation networks tends to be directly related to the number and complexity of value-add steps in an industrial sector.

The perception that Australia's public sector science was strong whilst business R\&D was weak was recognised in the 1980's and governments have maintained policies to "capitalise on public sector strengths by improving linkages with business" (Bryant et al. 1996). But poor collaboration has persisted, even though business R\&D expenditure has increased. A supply-side view of the difficult relationship between universities and business is reflected in the 2011-2021 Decadal Plan for Physics: "A key factor to improving collaboration between industry and research is recognition of the weaknesses associated with the publication-based metrics applied in Australia which do not capture 
nor reward entrepreneurialism and interactions with industry. In the current system, not only is there no incentive for researchers to enter industry temporarily, there is a strong disincentive for doing so" (Academy of Science 2012).

With one of the higher rates of researchers per 1000 population in higher education, but one of the lowest in business enterprises, a natural response might be to develop policy aimed at improving linkages between universities and business. This has indeed been attempted. But as Fontana et al. (2006) note: to "... consider university-industry relationships in a general way and develop policies on the basis of such generalizations will lead to unintended inter-sectoral differences...current policies are mainly directed to forcing PROs (Public Research Organisations) into these types of relationships with no acknowledgement that without appropriate 'demand' little will be achieved" (p. 206).

Mechanism: The national culture undervalues entrepreneurship and the motivation to create innovative businesses or initiate innovation within the firm is low. This complementary mechanism emerged in the course of looking for additional secondary data. Quality of life is high in Australia, ranked second on the Human Development Index (Malik 2013). Whilst Australia has good conditions and prospects for those who wish to become entrepreneurs, "only $54 \%$ of the Australian adult population consider entrepreneurship to be an interesting career path." This is far lower than most comparable developed nations (PriceWaterhouseCoopers 2013). A low personal motivation to be an entrepreneur, perhaps a comfortable complacency, emerges as a mechanism that inhibits the drive of people to improve their material circumstances through innovation. A similar profile to Australia in this regard is Norway, with a very high reliance on natural resources for export ( $3^{\text {rd }}$ highest in the $\mathrm{OECD}$, Australia is $\left.4^{\text {th }}\right)$, a high-wage country with a very high $\mathrm{HDI}$ ranking $(\mathrm{Nr} 1)$, and a poor performance in innovation translation $\left(51^{\text {st }}\right)$.

\section{Discussion}

The potential causes we identified in Stage 2 by sorting anomalies in the data-arising from factors such as the presence or absence of funds, skills, motivations and needs-are seen not as reified constructs or events, but as parts of an underlying reality that generate observable outcomes and exist independently of their perception. Further, these factors and the mechanisms they enter are different from and do not necessarily resemble the indicators that suggest their involvement. However, and as demonstrated in Stage 3 and using independent evidence, there is good reason to believe that the factors identified were actually present and causally effective in the Australian context. Of course, it is never possible to prove the existence and operation of such factors beyond any measure of doubt. But it is possible, in our view, to provide grounds for believing that they were present in the relevant situation, that their capacities were activated, and that they were probably not anticipated by other causal mechanisms or offset by countervailing causal mechanisms.

Our results are summarised in Figure 1, an interim model that provides a graphical representation of the causes we have identified, and which seeks to demonstrate how we mapped data to locate where the proposed mechanisms have links to the confirming sources within the macro, meso and micro levels of the Australian economy. The macro level is that of the national context comprising the regulations, funding, policies and general economic conditions that, in part, constitute the operating environment for business, markets and education. The micro level embodies the lived daily reality of individuals interacting with their peers and the desires, beliefs and opportunities that 
shape their actions. At the meso level, where decisions to innovate are actually made by business managers and entrepreneurs within their organisational contexts, the mechanisms are activated in the process of deciding whether to initiate, fund and support innovation.

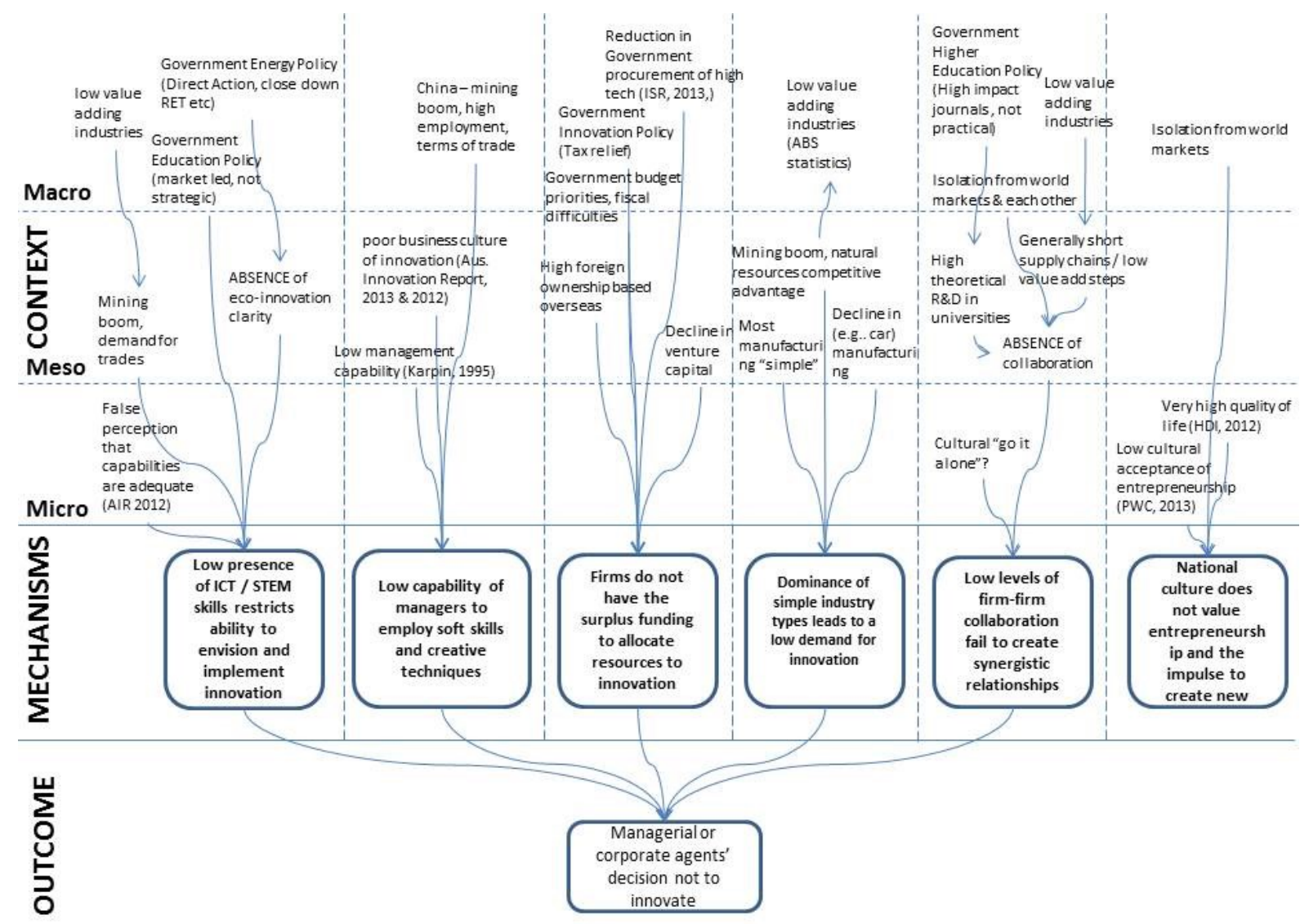

Figure 1: Causal factors discouraging business managers' innovation activities

We recognise of course that the list of causes reported in Figure 1 will never be complete or exhaustive. This should not be surprising, not only because there is usually no fixed point at which to stop adding antecedent causes in causal sequences, but also because the kind of theory building we are doing is by its nature always partial and provisional. We nevertheless hope that the diagram provides a potentially useful summary of the factors that may be inhibiting Australian innovation performance, and where these lie at different levels of social, business and governmental life. Some of these factors could be addressed by business and other organisations. Others will require government intervention in several areas. But the multiplicity of causes we have identified suggests that it is unlikely that picking winners or correcting "market failure" in a single component of the system (e.g. government procurement) will be successful (Chaminade and Edquist 2010).

Figure 1 does not however offer further guidance on policy development, which is something that requires an understanding of the causal interrelationships and dynamic dependencies between the mechanisms that might inhibit managers' propensity to conduct or at least support innovative activity. Figure 2 below offers a diagrammatic representation of the relationship between:

- underlying structures (such as an industrial sector)

- actual structural conditions (such as the dominance of low value-add industries) 
- resulting mechanisms (such as a low drive to collaborate) that can cause low innovation

We have also annotated the diagram to reflect the part of the national innovation system in which a structure or mechanism resides (Australian Government Department of Industry 2013; Edquist 2011). This makes it possible to integrate the data- and discovery-driven approach of retroduction with existing theory. Policy makers are thus assisted by being able to view the causal interactions between elements in different domains (such as collaboration, R\&D or networking) within a higherlevel conceptual model.

We begin by postulating that one of the main determinants of the overall level of innovation activity in an economy is the extent to which its output derives from technology intensive industries or industries in which knowledge is embedded via ICT into products and services (Godin 2004). Where production does not require sophisticated technology, businesses have little incentive to pursue innovation and the demand for deep skills in engineering and ICT will be low. These factors will in turn tend to inhibit the creation of collaboration networks, which are less in evidence in Australia than in countries with more complex value chains (such as Germany or Japan, $6^{\text {th }}$ and $3^{\text {rd }}$ respectively on the Cornell University et al. cluster development indicator). The synergies and dynamics associated with collaborating groups will then be absent too. Low demand for deep technology skills also leads to an absence of skilled people, which inhibits management's (already low by international standards) drive (and awareness) to innovate. This path dependency combines with a pre-existing, national culture of low entrepreneurship to create a decision-making context for reflexive managers that militates against innovation. The financial aspect is also important, but perhaps not decisive: without adequate funds (regardless of source), managers are hard-pressed to make decisions to innovate. 


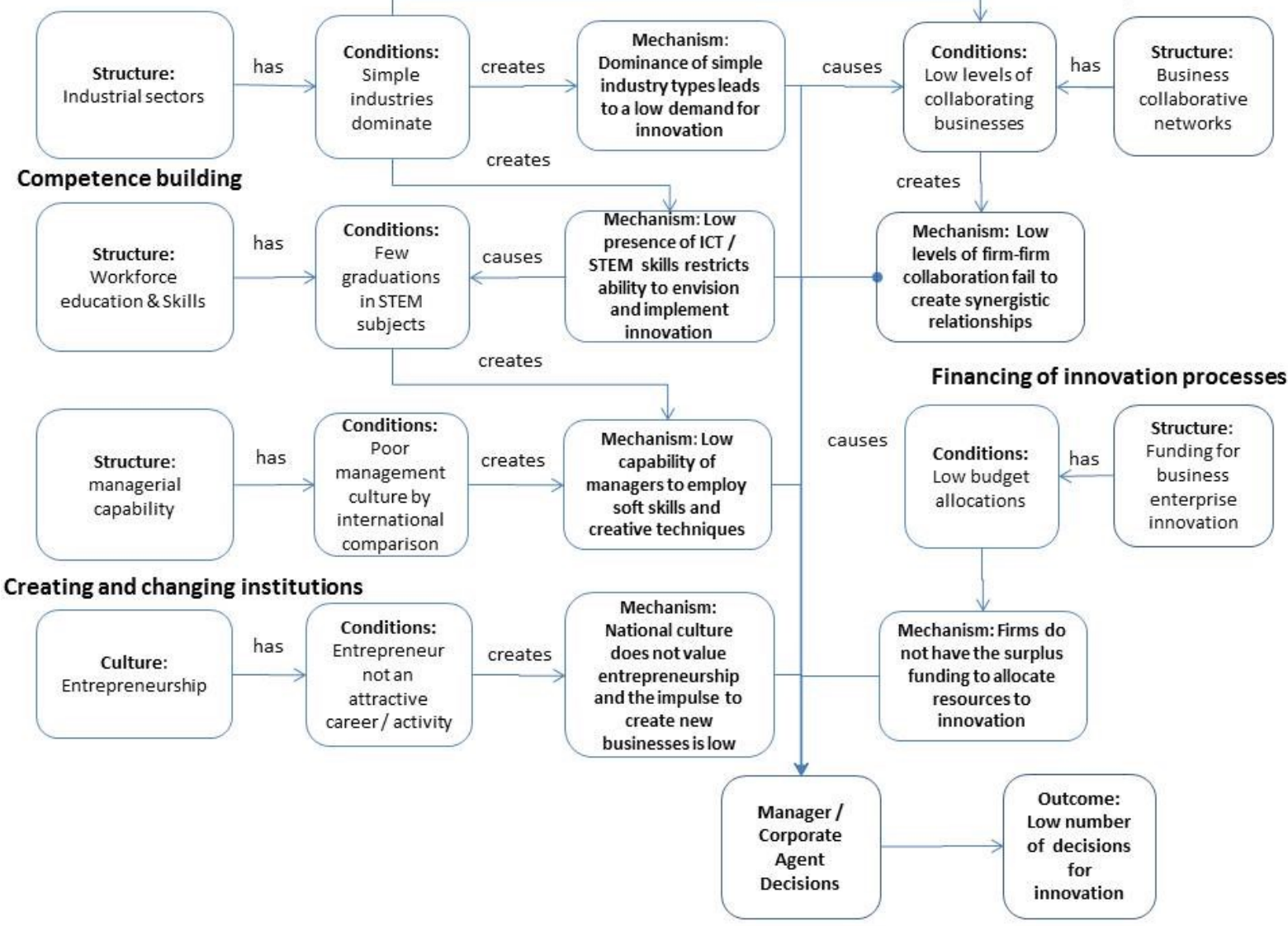

Figure 2: Causal Analysis of Mechanisms Influencing the Managerial Decision to Innovate

The full set of possible causes of low innovation efficiency is far larger than represented here. But our present explanatory interest is chiefly in the mechanisms that influence managers' propensity to innovate, and we believe these mechanisms, configured as they are in this model, constitute a sufficient set to begin additional, detailed investigation. Furthermore, the sequencing of mechanisms that we have proposed suggests that policy decisions to act upon consequent inhibitors are likely to be ineffectual if antecedent causes are ignored. Training more ICT specialists or engineers will be of limited use if there is low demand for such people from the relevant industrial sectors. For the same reason, underwriting clusters and networks with universities will not encourage collaboration if business has a low drive to search and innovate, or their respective motivations diverge.

\section{Conclusion}

We have provided a critical realist analysis of various causal mechanisms that may be responsible for Australia's poor performance in translating innovation inputs into innovation outputs. Exercises of this sort face two major challenges. The first is the sheer volume, and consequent difficulty of amassing, the data required to gain meaningful insight into something as large, complex and open as a national innovation system. It is for this reason that we relied principally on secondary data in the present paper. The second challenge is that the empirical corroboration of the relevant causes requires a detailed, nuanced understanding of the interplay between mechanism and context. This generally requires a careful and specific collection of primary data and specific case study. 
This paper is a response to the first challenge. Drawing on two reputable empirical sources, Cornell University et al. and the $O E C D$, we retroduced various causal mechanisms that may be inhibiting Australia's innovation efficiency. We isolated five such mechanisms in particular, and, using additional government reports and statistics, found independent evidence of the existence and operation of these mechanisms at the government (macro), industrial (meso) and individual (micro) level. We also uncovered an additional mechanism, that of a relatively low cultural drive to become an entrepreneur. On the basis of these findings we then constructed a sequence model of the mechanisms identified to provide a causal explanation of why Australia is so poor in translating its generally quite fertile innovation inputs into actual business innovation outputs. While we recognise that there may well be other factors not revealed by the data we used, we hope that we have been able to demonstrate that it is possible to achieve meaningful insights by applying the method of retroduction to secondary, quantitative and qualitative data.

Our chief aim was to demonstrate our approach as a viable means of exploiting aggregated national statistics. If the world does in fact comprise enduring structures and causal mechanisms to which we have only partial, mediated, empirical access, then a matching investigative method is required. We submit that proceeding as we have done-reviewing the statistical indicators, taking these as indicators of underlying structures, and using retroduction to postulate underlying causal mechanisms - provides a mode of analysis that has the "practical adequacy" to be useful to analysts and policy makers anywhere.

The next stage of research would be to address the second challenge, and in particular to explore via detailed case study work, the extent to which the mechanisms we have identified contribute to the indifference, if not resistance, to innovation displayed by Australian business managers. Such work might extend to investigating the role of managerial reflexivity in the innovation decision, and how reflexive managers perceive, reproduce or resist these mechanisms within the contexts in which they are operating. A key part of the exercise, using Figure 2 as a starting point, would be to pay attention to the interactions and sequencing of the relevant mechanisms, which will in turn help to inform the sequencing and prioritisation of policy initiatives.

\section{References}

Academy of Science (2012). Physics Decadal Plan 2012-2021: Building on Excellence in Physics. Canberra: Australian Research Council

Ackroyd, S., \& Fleetwood, S. (Eds.). (2000). Realist Perspectives on Organisation and Management. London: Routledge.

Archer, M. (1995). Realist Social Theory: The Morphogenetic Approach. Cambridge, UK: Cambridge University Press.

Archer, M. (2007). Making our way through the world. Cambridge: Cambridge University Press.Astbury, B., \& Leeuw, F. L. (2010). Unpacking Black Boxes: Mechanisms and Theory Building in Evaluation. American Journal of Evaluation, 31(3), 363-381, doi:10.1177/1098214010371972.

Australian Bureau of Statistics (2003). 8158.0 - Innovation in Australian Business, 2003 (Reissue). Canberra: Australian Bureau of Statistics,.

Australian Bureau of Statistics (2012). 8158.0 - Innovation in Australian Business, 2010-11. Canberra: Australian Bureau of Statistics,.

Australian Bureau of Statistics (2013a). 2013 Labour Statistics In Brief. Canberra: Australian Bureau of Statistics,. 
Australian Bureau of Statistics (2013b). 5368.0.55.006 - Characteristics of Australian Exporters, 201213 (Vol. 2015). Canberra: Australian Bureau of Statistics,.

Australian Government Department of Industry (2012). Australian Innovation System Report 2012. Canberra: Commonwealth of Australia.

Australian Government Department of Industry (2013). Australian Innovation System Report 2013. Canberra: Commonwealth of Australia.

Barczak, G., Griffin, A., \& Kahn, K. B. (2009). Perspective: trends and drivers of success in NPD practices: results of the 2003 PDMA best practices study. Journal of Product Innovation Management, 26(1), 3-23.

Bertrand, O. (2009). Effects of foreign acquisitions on R\&D activity: Evidence from firm-level data for France. Research Policy, 38(6), 1021-1031.

Bhaskar, R. (1978). A realist theory of science. Sussex. : Harvester Press.

Bhaskar, R. (2010). Contexts of interdisciplinarity: interdisciplinarity and climate change. In R. Bhaskar, C. Frank, K. G. Hoyer, P. Naess, \& J. Parker (Eds.), Inbterdisciplinarity and Climate Change (pp. 1-25). Abingdon: Routledge.

Bryant, K., Healy, M., \& Lombardo, L. (1996). Charting National Innovation Systems ? An Australian Approach. Paper presented at the Informal Workshop on National Innovation Systems, Paris, 3 October 1996

Butler, M., Wilkinson, J., \& Allen, P. (2010). Exploring Innovation in Policy-making within Central Government. Public Policy \& Adminsitration, 25(2), 137-155.

Chaminade, C., \& Edquist, C. (2010). Rationales for Public Policy Intervention in the Innovation Process: Systems of Innovation Approach. In R. E. Smits, S. Kuhlmann, \& P. Shapira (Eds.), The Theory and Practice of Innovation Policy (pp. 95-114). Cheltenham, UK: Edward Elgar.

Christensen, C., \& Overdorf, M. (2000). Meeting the challenge of disruptive change. Harvard Business Review, 78(2), 66-77.

Clark, A. M., Maclntyre, P. D., \& Cruickshank, J. (2007). A critical realist approach to understanding and evaluating heart health programmes. Health, 11(4), 513-539.

Collier, A. (1994). Critical Realism: An Introduction to Roy Bhaskar's Philosophy. London \& New York: Verso.

Cornell University, INSEAD, \& WIPO (2014). The Global Innovation Index 2014. In S. Dutta, \& B. Lanvin (Eds.). Fontainebleau, Ithaca, and Geneva: World Intellectual Property Organization.

Connelly, J. (2000). A realist theory of health sector management: the case for critical realism. Journal of Management in Medicine, 14(5/6), 262-271.

Cutler, T. (2008). Venturous Australia. Building Strength in Innovation. Cutler \& Company Pty Ltd.

Danneels, E. (2004). Disruptive technology reconsidered: A critique and research agenda. Journal of Product Innovation Management, 21(4), 246-258.

de Vaujany, F.-X. (2008). Capturing reflexivity modes in IS: A critical realist approach. Information \& Organization, 18(1), 51-72.

Dobson, P., Jackson, P., \& Gengatharen, D. (2013). Examining Broadband Adoption in Rural Australia - Modes of Reflexivity and the Morphogenetic Approach. MIS Quarterly, 37(3), 965-992.

Dodgson, M., \& Innes, P. (2006). Australian Innovation in Manufacturing: Results from an International Survey.

http://www.nswbusinesschamber.com.au/NSWBC/media/Misc/Ask\%20Us\%20How/Australi an-Innovation-in-Manufacturing.pdf. Accessed 20/8/2014.

Edquist, C. (2011). Design of innovation policy through diagnostic analysis: Identification of systemic problems (or failures) Industrial and Corporate Change, 20(6), 1-29, doi:10.1093/icc/dtr060.

Edquist, C., \& Chaminade, C. (2006). Industrial policy from a systems-of-innovation perspective. European Investment Bank Papers, 11(1), 109-132.

Faulkner, P., \& Runde, J. (2009). On the identity of technological objects and user innovations in function. Academy of Management Review, 34(3), 442-462. 
Faulkner, P., \& Runde, J. (2013). Technological objects, social positions and the transformational model of social activity. MIS Quarterly, 37(3), 803-818.

Fontana, R., Geuna, A., \& Matt, M. (2006). Firm size and openness: the driving forces of universityindustry collaboration. In Y. Caloghiru, A. Constantelou, \& N. Vonortas (Eds.), Knowledge Flows in European Industry (pp. 305-345). Abingdon: Routledge.

Freeman, C. (1995). The 'National System of Innovation'in historical perspective. Cambridge Journal of Economics, 19(1), 5-24.

Godin, B. (2004). The New Economy: what the concept owes to the OECD. Research Policy, 33(5), 679-690.

Green, R., \& Logue, D. (2009). Innovation Australia: How we measure up. In N. Taylor (Ed.), Australia Adjusting: Optimising National Prosperity in 2025. Melbourne: Committee for the Economic Development of Australia.

Guan, J., \& Chen, K. (2012). Modeling the relative efficiency of national innovation systems. Research Policy, 41(1), 102- 115.

Hagedoorn, J. (1993). Understanding the Rationale of Strategic Technology Partnering: Interorganizational Modes of Cooperation and Sectoral Differences. Strategic Management Journal, 14, 371-385.

Horrocks, I. (2009). Applying the morphogenetic approach: outcomes and issues from a case study of information systems development and organisational change in British local government. Journal of Critical Realism, 8(1), 35-62.

Hung, S.-C., \& Whittington, R. (2011). Agency in national innovation systems: Institutional entrepreneurship and the professionalization of Taiwanese IT. Research Policy, 40(4), 526538.

Karpin, D. S. (1995). Enterprising Nation - Renewing Australia's Managers to Meet the Challenges of the Asia-Pacific Century. Report of the Industry Task Force on Leadership and Management Skills. Canberra: Australian Government Pub. Service.

Kontos, P. C., \& Poland, B. D. (2009). Mapping New Theoretical and Methodological Terrain for Knowledge Translation: Contributions from Critical Realism and the Arts. Implementation Science, 4(1), 1-10.

Koutsouris, A. (2012). Facilitating Agricultural Innovation Systems: a critical realist approach. Studies in Agricultural Economics, 114, 64-70.

Kuhlmann, S., Shapira, P., \& Smits, R. (2010). Innovation. A Systemic Perspective: The Innovation Policy Dance. In R. E. Smits, S. Kuhlmann, \& P. Shapira (Eds.), The Theory and Practice of Innovation Policy (pp. 1-22). Cheltenham, UK: Edward Elgar.

Lawson, T. (1995). A Realist perspective on contemporary" Economic Theory". Journal of Economic Issues, 29(1), 1-32.

Lawson, T. (1997a). Economics and Reality. London and New York: Routledge.

Lawson, T. (1997b). Situated rationality. Journal of Economic Methodology, 4(1), 101-125.

Lawson, T. (2003). Reorienting economics. London and New York: Routledge.

Lawson, T. (2006). The nature of heterodox economics. Cambridge Journal of Economics, 30, 483505.

Lawson, T. (2012). Ontology and the study of social reality: emergence, organisation, community, power, social relations, corporations, artefacts and money. Cambridge Journal of Economics, 36(2), 345-385.

Liu, J. S., Lu, W. M., \& Ho, M. H. C. (2015). National characteristics: innovation systems from the process efficiency perspective. R\&D Management, 45(4), 317-338.Lundvall, B. Å. (2007). National innovation systems - analytical concept and development tool. Industry and innovation, 14(1), 95-119.

Mahroum, S., \& Al-Saleh, Y. (2013). Towards a functional framework for measuring national innovation efficacy. Technovation, 33(10), 320-332.

Malik, K. (2013). Human Development Report 2013. United Nations Development Programme. 
Markham, S. K. (2013). The Impact of Front-End Innovation Activities on Product Performance. Journal of Product Innovation Management, 30(S1), 77-92.

Maxwell, J. (1992). Understanding and validity in qualitative research. Harvard Educational Review, 62(3), 279-301.

Maxwell, J. (2004). Using Qualitative Methods for Causal Explanation. Field Methods, 16(3), 243-264.

Mingers, J., Mutch, A., \& Willocks, L. (2013). Critical Realism in Information Systems Research. MIS Quarterly, 37(3), 795-802.

Nicholson, B. (2014, July 28). Door opens to buying foreign submarines. In: The Australian. Retrieved from http://www.theaustralian.com.au/national-affairs/policy/door-opens-to-buyingforeign-submarines/story-e6frg8yo-1227003572522?=

OECD (2011). OECD Science, Technology and Industry Scoreboard 2011. OECD Publishing.

OECD (2013a). Entrepreneurship at a Glance. OECD Publishing.

OECD (2013b). OECD Science, Technology and Industry Scoreboard. OECD Publishing.

Osborne, S., \& Brown, L. (2011). Innovation, public policy and public services delivery in the UK: the word that would be King? Public Administration, 89(4), 1335-1350.

Pawson, R., \& Tilley, N. (1997). Realistic Evaluation. London: Sage Publications.

Peirce, C. S. (1911). Letter to J. H. Kehler In J. H. Kehler (Ed.): Commens - Digital Companion to C. S. Peirce.

Pielke, R. (2004). What future for the policy sciences? Policy Sciences, 37(3-4), 209-225.

Potter, K., Smith, M., McGittigan, J., Guevara, J. K., Hall, L., \& Stegman, E. (2013). IT Metrics: IT Spending and Staffing Report, 2012. Gartner.

PriceWaterhouseCoopers (2013). The Startup Economy - How to support tech startups and accelerate Australian innovation

PriceWaterhouseCoopers (2014). Funding Australia's future: innovation \& digital technologies. http://www.pwc.com.au/media-centre/2014/innovation-digital-technologies-Apr14.htm. Accessed 1/08/2014.

Productivity Commission (2014). PC Productivity Update, April. In Australian Government Productivity Commission (Ed.). Melbourne: Commonwealth of Australia.

Rammer, C. (2006). Innovation in Firms. In U. Schmoch, C. Rammer, \& H. Legler (Eds.), National Systems of Innovation in Comparison (pp. 107-132). Dordrecht, Netherlands: Spinger.

Reserve Bank of Australia (2011). Statement Boxes 2011 - Box B: The Mining Sector and the External Accounts.

Runde, J. (1998). Assessing causal economic explanations. Oxford Economic Papers, 50, 151-172.

Trounson, A. (2014, April 14). Firms forced to look abroad to fill IT skills gap. The Australian. Retrieved from http://www.theaustralian.com.au/higher-education/firms-forced-to-lookabroad-to-fill-it-gap/story-e6frgcjx-1226858413137

Sayer, A. (1992). Method in social science; a realist approach. London: Routledge.

Sharaput, M. (2012). The limits of learning: Policy evaluation and the Ontario Ministry of Research and Innovation. Canadian Public Administration, 55(2), 248-267.

Shepherd, T. (2013, June 6). South Australian ship builders cut out of contracts as Federal Government buys overseas. In: The Adelaide Advertiser. Retrieved from http://www.adelaidenow.com.au/news/south-australia/south-australian-ship-builders-cutout-of-contracts-as-federal-government-buys-overseas/story-fni6uo1m-1226945174449

Song, M., Podoynitsyna, K., Van Der Bij, H., \& Halman, J. I. (2008). Success Factors in New Ventures: A Meta-analysis. Journal of Product Innovation Management, 25(1), 7-27.

Thorhildur, J., Avital, M., \& Bjørn-Andersen, N. Generating Value from Open Government Data. In Thirty Fourth International Conference on Information Systems, Milan 2013, Milan, 2013

Firms forced to look aborad to fill IT skills gap. (2014, 13/4/2014). The Australian.

Walker, R. (2006). Innovation type and diffusion: an empirical analysis of local government. Public Administration, 84(2), 311-335. 
Warren, M. (2012). The contribution of Mining Technology to the economy of Australia -and its Global Impact.

http://www.austmine.com.au/Portals/25/Content/News/Attachments/Austmine Perth\%20 30\%20Jan\%202012.pdf. Accessed 1/8/2014 2014.

Wirtz, B. W., Schilke, O., \& Ullrich, S. (2010). Strategic development of business models: implications of the Web 2.0 for creating value on the internet. Long Range Planning, 43(2), 272-290.

World Economic Forum (2014). The Global Competitiveness Report 2014-2015. Switzerland: World Economic Forum.

Wynn, D., \& Williams, C. (2012). Principles for conducting critical realist case study research in information systems. MIS Quarterly, 36(3), 787-810.

Zachariadis, M., Scott, S., \& Barrett, M. (2013). Methodological implications of critical realism for mixed-methods research. MIS Quarterly, 37(3), 855-879. 